\title{
SKUTKI ZMIAN W SYSTEMIE WYBORCZYM ORGANÓW JEDNOSTEK SAMORZĄDU TERYTORIALNEGO WYNIKAJĄCYCH Z USTAWY Z 11 STYCZNIA 2018 R.
}

\author{
EFFECTS OF CHANGES IN THE ELECTORAL SYSTEM OF LOCAL \\ GOVERNMENT UNITS RESULTING \\ FROM THE ACT OF 18 JANUARY 2018
}

Michał Klonowski*๑, Maciej Onasz** $\odot$$$
\text { ABSTRAKT }
$$

Artykuł stanowi próbę oceny skutków wprowadzenia zmian w systemie wyborczym organów jednostek samorządu terytorialnego wynikających z ustawy o zmianie niektórych ustaw w celu zwiększenia udziału obywateli w procesie wybierania, funkcjonowania i kontrolowania niektórych organów publicznych przyjętej w 2018 roku. Autorzy weryfikują hipotezy postawione przed zastosowaniem nowego systemu w praktyce, dotyczące wpływu zmian na proporcjonalność wyborów oraz możliwości uzyskania samodzielnej większości przez jedno ugrupowanie w organach stanowiących na poziomie gminy oraz ryzyka całkowitej dominacji jednego podmiotu w tym organie. Ocenie poddano również wpływ ograniczenia możliwości wykorzystywania biernego prawa wyborczego w wyborach do rad przez osoby kandydujące do organu wykonawczego w gminie.
\end{abstract}

The article is an attempt to assess the effects of introducing changes to the electoral system of local government units in 2018. The authors verify the hypotheses put forward before the application of the new system in practice, regarding the impact of changes on the proportionality of elections to municipal councils, the possibility of gaining an absolute majority by one party and the risk of total domination of one party in the municipal council. The impact of limiting the possibility of using the passive suffrage in elections to councils by candidates for the executive body in the commune was also assessed.

* Uniwersytet Łódzki, Wydział Studiów Międzynarodowych i Politologicznych.

** Uniwersytet Łódzki, Wydział Studiów Międzynarodowych i Politologicznych. 
Słowa kluczowe: samorząd terytorialny; wybory samorządowe; proporcjonalność wyborów; rada gminy; bierne prawo wyborcze; partycypacja obywatelska
Keywords: local government; local elections; proportionality of elections; commune council; passive suffrage; citizen participation

\section{WSTĘP}

System samorządowy w Polsce ulega ciągłym zmianom i mniejszym korektom. Jednak w zakresie zmian w systemie wyborczym do organów samorządu reforma ze stycznia 2018 była zdecydowanie największą od uchwalenia Kodeksu wyborczego w 2011 roku. Wstępną analizą kluczowych zapisów ustawy o zmianie niektórych ustaw w celu zwiększenia udziału obywateli w procesie wybierania, funkcjonowania i kontrolowania niektórych organów publicznych ${ }^{1}$ Autorzy niniejszego artykułu zajęli się już wcześniej (Klonowski, Onasz, 2018, ss. 99-117), stawiając przy okazji kilka hipotez, których weryfikacja stała się możliwa dopiero po kolejnej elekcji samorządowej jesienią 2018 roku.

Ustawa z 2018 roku wprowadziła wiele zmian, jednak w niniejszym artykule Autorzy zajmą się tymi, które dotyczą formuły wyborczej ${ }^{2}$ oraz biernego prawa wyborczego. W tym zakresie zmieniono przede wszystkim formułę wyborczą w gminach powyżej 20 tys. mieszkańców, niebędących miastami na prawach powiatu ${ }^{3}$, gdzie zamiast wcześniej stosowanej formuły reprezentacji większościowej, wprowadzono formułę reprezentacji proporcjonalnej (wykorzystującą metodę D'Hondta). Ustawa wprowadziła także ograniczenie liczby kadencji WBP do dwóch (choć nie liczonych wstecz), a także ograniczyła możliwości jednoczesnego ubiegania się kandydatów na WBP o mandat w organach stanowiących jednostek samorządu terytorialnego (JST) jedynie do rady gminy/ miasta, w której kandydują oni do organów wykonawczych. Jak sugeruje sam tytuł ustawy, celem reformy było zwiększenie udziału obywateli w procesie wybierania, funkcjonowania i kontrolowania niektórych organów publicznych, co w zakresie elekcji tychże można rozumieć jako dążenie do zwiększenia reprezentacyjności, dlatego też ten aspekt stanowi główną oś niniejszego artykułu. W związku z tym Autorzy nie poruszają kwestii związanych z innymi zmianami,

1 Dz.U. z 2018 r., poz. 130.

2 Rozumianej jako funkcja przekształcająca zbiór indywidualnych decyzji wyborczych jednostek w okręgu na zbiór mandatów.

3 Dalej w tekście: MNPP. 
takimi jak: wydłużenie kadencji, poszerzenie kompetencji komisarzy wyborczych czy nowa definicja znaku „X”.

Skutki zmian w systemie wyborczym organów JST były przedmiotem badań, szczególnie w odniesieniu do zmian wprowadzonych przed elekcją w roku 2014 (wprowadzonych przy okazji uchwalenia Kodeksu Wyborczego), uwzględnić w tym miejscu należy m.in. prace A. Gendźwiłła i T. Źółtaka (2016) czy J. Flisa i D. Stolickiego (2017). Również zmiana w roku 2018 stała się przedmiotem badań, szczególnie jednak z perspektywy nauk prawnych, nie zaś politologii, wśród których znalazły się ogólne analizy wraz z oceną prawno-konstytucyjną samych zmian, jak i trybu ich wprowadzenia (Rakowska-Trela, 2018a), ich zestawienie z zasadą demokratycznego państwa prawa (Rakowska-Trela, 2018b) oraz ogólne analizy pod kątem zgodności zmian z europejskimi standardami wyborczymi (Rulka, 2018). Istotna część prac, pozostając w spektrum nauk prawnych, koncentrowała się na zmianach dotyczących administracji wyborczej i kwestiach organizacyjnych (Hermeliński, 2018; Niżnik-Mucha, 2018; Sokala, 2018), do których należy również zaliczyć analizy przeprowadzone z uwzględnieniem oceny wykorzystania nowych rozwiązań w praktyce (Czapiewski, Miszczuk, 2019; Haman, 2018). Inne przedstawiały perspektywę historyczną zmian systemu (Woźnicki, 2020) lub skupiały się na wybranym aspekcie zmian, np. roli komisarzy wyborczych (Frydrych-Depka, 2018; Woźnicki, 2018), procedur związanych z ustaleniem struktury okręgów wyborczych (Balicki, 2018; Masternak-Kubiak, 2018) czy praktyki funkcjonowania obwodowych komisji wyborczych w nowej formule (Pyrzyńska, 2020). Wybrane aspekty skutków reformy były również przedmiotem badań politologicznych lub interdyscyplinarnych. Należy w tym miejscu uwzględnić prace B. Michalaka, który zastosował podejście podobne jak autorzy niniejszego artykułu, tj. przedstawił zarówno ocenę wprowadzonych zmian (2018), jak i ich praktycznych skutków (2019), wcześniej już wspomnianych A. Gendźwiłła i T. Żółtaka (2020), którzy poddali analizie wpływ zmian na reprezentację sformalizowanych partii politycznych w samorządzie, czy Jakuba Neumanna (2020), który zanalizował wpływ zmian na kształt oferty wyborczej, wreszcie pracę K. Urbaniaka (2020), badającego wpływ zmian na realizację zasady proporcjonalności. Zbliżone podejście metodologiczne do wykorzystanego przez Autorów zastosował M. Glinka (2020) w kompleksowej (choć poświęconej gminom Dolnego Śląska) pracy dotyczącej politycznych konsekwencji zmian z roku 2018. Zagadnienie skutków zastosowania poszczególnych elementów systemu wyborczego od lat pozostaje przedmiotem badań politologicznych, przez co doczekało się wielu opracowań, ze szczególnym uwzględnieniem udziału prac takich autorów jak D.W. Rae, J, Loosemore i V. J. Hanby (1971), R. 
Taagepera i M. S. Shugart (1989), M. Gallagher (1991), K. Benoit (2000) czy B. Grofman i (ponownie) R. Taagepera (2003). Niniejszy artykuł stanowi próbę odniesienia wcześniejszych ustaleń na grunt polski, konkretniej - do organów jednostek samorządu terytorialnego.

\section{HIPOTEZY BADAWCZE}

Skupiając na zmianach $\mathrm{w}$ formule wyborczej oraz dotyczących biernego prawa wyborczego, wskazano cztery hipotezy, które zostały poddane weryfikacji. Po pierwsze Autorzy założyli, że wprowadzenie wyborów proporcjonalnych (a w zasadzie ich przywrócenie) w gminach powyżej 20 tys. mieszkańców (niebędących MNPP) spowoduje, iż wyniki wyborów będą w większym stopniu odzwierciedlać wyniki głosowania (H1). Zjawisko to powinno być widoczne zarówno w porównaniu z poprzednią elekcją z 2014 roku, jak i w porównaniu z gminami poniżej 20 tys. mieszkańców. Po drugie Autorzy spodziewali się, że w gminach powyżej 20 tys. mieszkańców może być utrudnione uzyskanie samodzielnej większości (H2). Powinno to być widoczne zarówno w odniesieniu do roku 2014, jak i do pozostałych gmin. W powiązaniu z nią pojawiła się jeszcze jedna hipoteza, mianowicie że ryzyko uzyskania przez jedno ugrupowanie wszystkich mandatów $\mathrm{w}$ radzie zostanie ograniczone do gmin powyżej 20 tys. mieszkańców (H3). Ponieważ jedną z istotniejszych zmian wprowadzonych w styczniu 2018 roku był zakaz kandydowania jednocześnie na wójta, burmistrza lub prezydenta miasta (dalej w skrócie WBP) i do rad poza radą tej samej gminy, przedstawiono kolejną hipotezę, zgodnie z którą częściej niż wcześniej kandydowanie na WBP będzie łączone na tym poziomie (w miejsce łączenia $\mathrm{z}$ kandydowaniem do rady powiatu lub sejmiku), co będzie skutkowało koniecznością przeprowadzenia większej liczby wyborów uzupełniających wynikających $\mathrm{z}$ jednoczesnego zwycięstwa $\mathrm{w}$ wyborach WBP oraz do rady gminy do 20 tys. mieszkańców (co będzie generować dodatkowe koszty finansowe) (H4).

\section{DANE I METODY}

W celu weryfikacji postawionych hipotez Autorzy posłużyli się wynikami głosowania oraz wynikami wyborów organów jednostek samorządu terytorialnego (rad gmin i miast oraz wójtów, burmistrzów i prezydentów miast) w latach 2014 
i 2018. Wykorzystano zarówno dane dostępne w serwisach informacyjnych Państwowej Komisji Wyborczej (PKW), jak i bazy danych udostępnione przez PKW oraz Krajowe Biuro Wyborcze (KBW) na prośbę Autorów.

W badaniu nie uwzględniono wyborów Rady Miasta oraz Prezydenta Miasta Zielona Góra w roku 2014 (zostało ono przeprowadzone w innym terminie ze względu na zmianę granic gminy). W częściach badania wykorzystujących wskaźniki dysproporcjonalności wykluczono gminy, w których nie odbyło się głosowanie (wszystkie mandaty zostały rozdysponowane w wyborach niekonkurencyjnych w wyniku zgłoszenia się liczby kandydatów odpowiadającej liczbie mandatów (Stępień, 2018).

W tym miejscu należy zwrócić uwagę na specyficzne trudności, na jakie natknęli się Autorzy w badaniu służącemu weryfikacji hipotezy IV. Bazy danych udostępnione Autorom stanowiły wyciąg z baz danych PKW i KBW dotyczących wyborów samorządowych w latach 2014 i 2018. Dane te nie były jednak wprowadzane przez pracowników centralnych instytucji odpowiedzialnych za przeprowadzenie wyborów, ale przez członków właściwych terytorialnych komisji wyborczych. Dane te były wpisywane bezpośrednio przez członków komisji (czyli nie były importowane np. z bazy PESEL). Zważywszy ogromną liczbę zestawów danych ${ }^{4}$, zrozumiałe wydaje się, że część wartości została wprowadzona błędnie. Wśród najczęstszych należy wskazać: błędny zapis imienia lub nazwiska (szczególnie dotyczy to nazwisk obcego pochodzenia ${ }^{5}$ ), niejednolity zapis podwójnego nazwiska ${ }^{6}$, pominięcie drugiego imienia ${ }^{7}$, czysto techniczny błąd polegający na oddzieleniu imion kandydata wielokrotną (dwukrotną) spacją ${ }^{8}$ czy błędne obliczenie wieku kandydata ${ }^{9}$, jak również niejednolity zapis nazw

4 Dotyczyły one 8029 kandydatów na WBP oraz 233090 kandydatów do rad w roku 2014 oraz, odpowiednio, 6958 i 184745 w 2018.

5 Np. Milan Ušák / Milan Ušàk jako kandydat na burmistrza Siechnic/radnego powiatu wrocławskiego w roku 2014. W kolejnych wyborach nie powtórzono tego błędu - zarówno jako (ponownie) kandydata na burmistrza jak i kandydata do rady miasta Siechnice, zarejestrowano go jako Milan Ušák.

6 Np. Kilar-Błaszczyk i Kilar - Błaszczyk.

7 Najczęściej dotyczyło to kandydowania do rad.

8 Innym, podobnym błędem utrudniającym analizę było dopisywanie spacji np. po nazwisku kandydata.

9 Dotyczy to sytuacji, w których ta sama osoba, kandydująca na wójta/burmistrza/prezydenta miasta oraz do rady w obu elekcjach, miała przypisana różne wartości dotyczące wieku. Prawdopodobnie w wielu przypadkach może to wynikać ze stosowania zamiennie dokładnego odniesienia do wieku na dzień głosowania oraz odniesienia rocznikowego. 
miejscowości ${ }^{10}$. Osoby wprowadzające dane nie uniknęły również zwyczajnych literówek ${ }^{11}$. Innym (mogącym niepokoić $\mathrm{z}$ uwagi na uwarunkowania biernego prawa wyborczego w wyborach rad gmin) zaobserwowanym zjawiskiem jest wskazywanie przez kandydatów, startujących zarówno na urząd wójta, jak i do rady, różnych miejsc zamieszkania w trakcie zgłoszeń w obu elekcjach ${ }^{12}$. Autorzy dołożyli wszelkich, możliwych starań, aby zidentyfikować powstałe nieprawidłowości i aby nie zafałszowały one wyniku badania. Przedstawione hipotezy zostały zweryfikowane $\mathrm{z}$ wykorzystaniem właściwych im metod:

H1-H3: Dla celów badania wyodrębniono 3 grupy gmin: 1) Grupa badana: gminy powyżej 20 tys. mieszkańców (z wyłączeniem MNPP), w których nastąpiła całościowa zmiana systemu wyborczego ${ }^{13}$; 2) Grupa kontrolna: gminy do 20 tys. mieszkańców, w których system wyborczy pozostał bez zmian; 3) Druga grupa kontrolna: MNPP, w których w wyborach w latach 2014 i 2018 miał zastosowanie system wyborczy tożsamy z zastosowanym w grupie badanej w roku $2018^{14}$. Tożsamy podział został zastosowany w procesie weryfikacji hipotezy $\mathrm{H} 4$, mimo że badana zmiana (dotycząca biernego prawa wyborczego) dotyczyła w tożsamym zakresie wszystkich grup gmin.

H1: Dla obliczenia stopnia odwzorowania wyniku głosowania w wyniku wyborów posłużono się powszechnie stosowanymi współczynnikami (indeksami) dysproporcjonalności: Loosemore-Hanby'ego (Loosemore, Hanby, 1971, ss. 467-469) oraz Gallaghera (Gallagher, 1991, ss. 40-41). Oba określają poziom dysproporcjonalności między odsetkiem głosów uzyskanych przez ugrupowanie a odsetkiem przyznanych temu ugrupowaniu mandatów.

Indeks dysproporcjonalności Loosemore-Hanby’ego (LHI) oblicza się z wykorzystaniem wzoru:

10 Np. Gryfów Śląski / Gryfów Śl; Długopole-Zdrój / Długopole Zdrój; Płonne-Plebanka / Płonne Plebanka; Tereszpol-Zygmunty / Tereszpol - Zygmunty; Wybudowanie Łasińskie i Łasin Wybudowanie; Lubicz / Lubicz Dolny; Kumów Majoracki / Kumów; Gościeradów POM / Gościeradów; Wilkołaz Pierwszy / Wilkołaz; Zakrzew-Kolonia i Zakrzew; Szczekarków Kolonia / Kolonia Szczekarków; Wożuczyn - Cukrownia / Wożuczyn; Gołaczewy Kolonia Chełmska / Gołaczewy Kol. Chełmska.

11 Np. Strzelce Krajeńksie (Strzelce Krajeńskie), Krepiny (Krępiny).

12 Np. Bożena Kończak, w roku 2014 kandydatka na burmistrza Kamiennej Góry oraz do rady powiatu kamiennogórskiego. W pierwszym przypadku jako jej miejsce zamieszkania wskazano Janiszów, w drugim Przedwojów.

13 Dla zachowania przejrzystości tekstu Autorzy określają tę grupę jako gminy powyżej 20 tys. mieszkańców - każdorazowo należy pamiętać, że nie są do niej zaliczane MNPP.

$14 \mathrm{Z}$ niewielkimi zmianami dotyczącymi maksymalnej liczby mandatów w okręgu. 


$$
\mathrm{LHI}=\frac{\sum_{\mathrm{i}=1}^{\mathrm{n}}\left|\mathrm{v}_{\mathrm{i}}-\mathrm{s}_{\mathrm{i}}\right|}{2}
$$

natomiast indeks dysproporcjonalności Gallaghera $\mathrm{GHI}=\sqrt{\frac{\sum_{i=1}^{n}\left(\mathrm{v}_{\mathrm{i}}-\mathrm{s}_{\mathrm{i}}\right)^{2}}{2}}$,

gdzie $v_{i}$ oraz $s_{i}$ oznaczają odpowiednio odsetek głosów oraz odsetek mandatów uzyskanych przez ugrupowanie (partię, komitet) i. Oba wskaźniki przyjmują wartość z zakresu od 0 do 1 (od $0 \%$ do $100 \%$ ). W obu przypadkach wartość indeksu 0 oznacza zachowanie pełnej proporcjonalności (odsetek mandatów każdego ugrupowania jest równy odsetkowi uzyskanych głosów), zaś wartość indeksu 1 oznacza skrajną dysproporcjonalność (wszystkie mandaty uzyskało ugrupowanie, które nie uzyskało żadnego głosu). Cechą różnicującą oba współczynniki jest mniejsza wrażliwość GHI na niewielkie wartości różnic między $\mathrm{v}_{\mathrm{i}}$ a $\mathrm{s}_{\mathrm{i}}{ }^{15}$.

$\mathrm{W}$ ramach badania:

1. porównano średnią wartość współczynników LHI i GHI w grupie badanej w wyborach 2014 i 2018. Wyniki porównano również z obydwiema grupami kontrolnymi.

Aby wykluczyć możliwe zaburzenia, zbadano również:

1. wartość współczynników LHI i GHI w grupie badanej w wyborach 2014 i 2018 wraz z porównaniem z grupami kontrolnymi z wyłączeniem gmin, w których przynajmniej jeden mandat został obsadzony w wyborach niekonkurencyjnych;

2. wartość współczynników LHI i GHI w wyborach 2014 i 2018 w podgrupach grupy badanej (gminy wiejskie, miejskie, miejsko-wiejskie);

3. średnią liczbę komitetów wyborczych w wyborach 2014 i 2018 w grupie badanej oraz kontrolnych ( $w$ odniesieniu do liczby gmin oraz liczby mandatów);

4. średnią liczbę kandydatów wyborczych w wyborach 2014 i 2018 w grupie badanej oraz kontrolnych (w odniesieniu do liczby gmin oraz liczby mandatów);

5. zależność wartości współczynników LHI i GHI w wyborach 2014 i 2018 od liczby kadencji urzędowania WBP (w całym zbiorze oraz w grupach gmin).

15 Porównując wartość obu współczynników dla dwóch sytuacji, w których suma wartości |vi-si| jest równa, ale różnią się one rozkładem wartości, np.: $\mid$ vi-si $\mid=\{0,1 ; 0,15 ; 0,05\}$ oraz $\mid$ vi-si $\mid=\{0,1 ; 0,05 ; 0,05$; $0,05 ; 0,05\}$, wartość LHI dla obu sytuacji wyniesie 0,15 , zaś GHI w pierwszej 0,1322 a w drugiej 0,1 . 
H2: Dla weryfikacji postawionej hipotezy porównano częstość samodzielnej większości w grupie badanej w wyniku wyborów w roku 2014 i 2018 . Wyniki porównano z obydwiema grupami kontrolnymi. Aby wykluczyć inne, możliwe zaburzenia, zbadano również zależność częstości samodzielnej większości od liczby kadencji urzędowania wójta/burmistrza/prezydenta miasta (w całym zbiorze oraz w grupach gmin) w wyborach 2014 i 2018.

H3: Dla weryfikacji postawionej hipotezy zbadano udział procentowy najsilniejszego ugrupowania w radzie w wyborach 2014 i 2018 (w całym zbiorze oraz w grupach gmin). Badanie uzupełniono o analizę wykorzystującą wartości naturalnych progów wyborczych - progu włączenia (threshold of inclusion) oraz wyłączenia (threshold of exclusion) (Rae, Hanby, Loosemore, 1971, ss. 479-488; Gallagher, 1992, s. 486). Pierwszy z nich określa granicę poparcia w okręgu, której przekroczenie daje wyższą od zera szansę na uzyskanie mandatu (lub określonej ich liczby), natomiast drugi - granicę poparcia w okręgu, której przekroczenie dające gwarancję uzyskania mandatu (lub określonej ich liczby). Dla formuły większości względnej w jednomandatowych okręgach wyborczych przyjmują one wartość: próg włączenia $T_{I[p]}=\frac{1}{N}$; próg wyłączenia $T_{N[p]}=\frac{1}{S+1} \quad$ (zatem, w każdym przypadku jest równe 50\%). Dla formuły reprezentacji proporcjonalnej wykorzystującej metodę D'Hondta w okręgach wielomandatowych, odpowiednio $T_{I\left[D^{\prime} t\right]}=i\left(\frac{1}{S+N-1}\right) \operatorname{oraz} T_{N\left[D^{\prime} t\right]}=i\left(\frac{1}{S+1}\right)$, gdzie $S$ oznacza liczbę mandatów w okręgu, $\mathrm{N}$ - liczbę list w okręgu (pojedyncza kandydatura w okręgu jednomandatowym jest traktowana jako lista), i - liczbę mandatów, których uzyskanie jest rozpatrywane.

H4: Dla weryfikacji postawionej hipotezy zbadano liczbę oraz częstość występowania zwycięskich kandydatów na WBP kandydujących również do rad w wyborach 2014 i 2018 (w całym zbiorze oraz w grupach gmin).

\section{PREZENTACJA WYNIKÓW ANALIZY}

H1: Dla weryfikacji postawionej hipotezy badaniu poddano poziom dysproporcjonalności (mierzony wskaźnikami LHI oraz GHI) w grupie badanej oraz grupach kontrolnych w wyborach 2014 i 2018 roku. Wyniki zostały przedstawione na wykresie 1.

Średnie wartości współczynników LHI oraz GHI dla gmin grupy badanej w roku 2014 były wyższe niż w grupach kontrolnych ( 0,27 i 0,19 względem 0,22 i 0,16 [gminy do 20 tys.] oraz 0,17 i 0,11 [MNPP]). Wśród możliwych przyczyn 


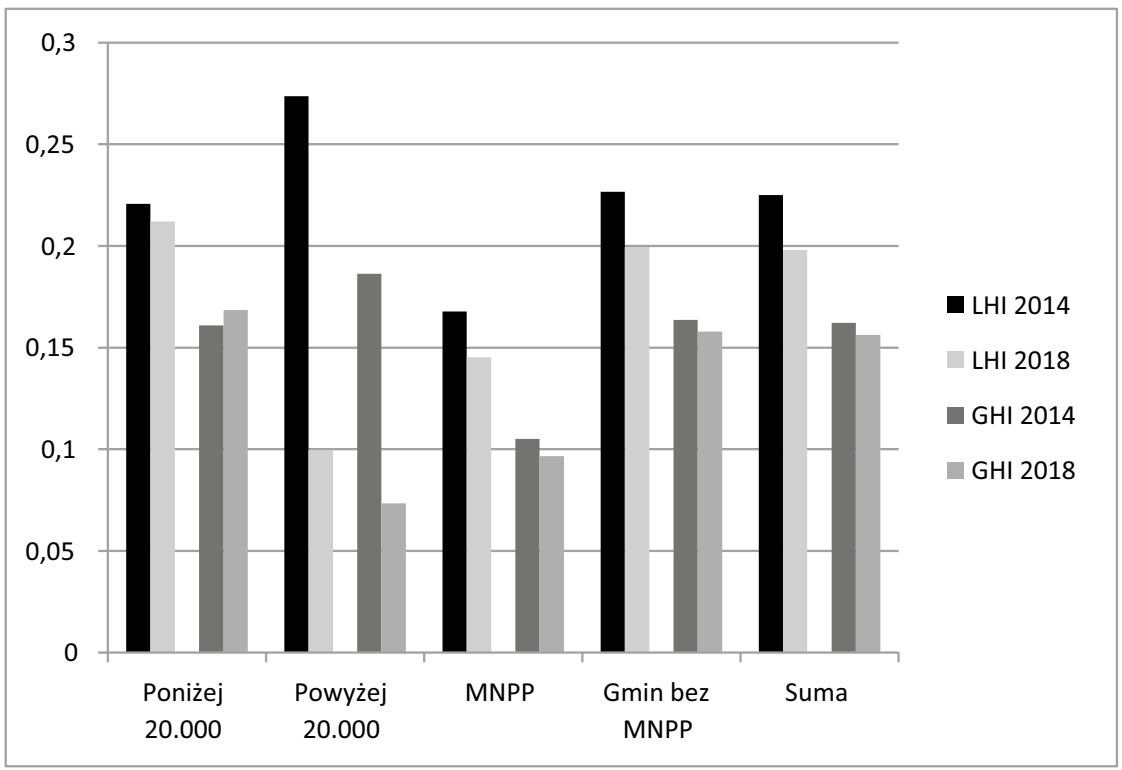

Wykres 1. Średnia wartość współczynników dysproporcjonalności LHI i GHI w typach gmin w wyborach 2014 i 2018 r.

Źródło: Opracowanie własne na podstawie danych PKW.

takiego stanu należy wskazać potencjalne niedostosowanie podmiotów lokalnych systemów partyjnych do zmiany systemu wyborczego przed wyborami w roku 2014 oraz ograniczone kompetencje, dotyczące poruszania się w zmienionym systemie, wśród wyborców. Ponowna zmiana systemu (a właściwie - przywrócenie systemu wcześniejszego) w roku 2018 spowodowała radykalne obniżenie średniej wartości współczynników LHI oraz GHI w grupie badanej (do 0,10 i 0,07). Kierunek zmiany jest zgodny $\mathrm{z}$ większością obserwacji dla grup kontrolnych (LHI w gminach do 20 tys. i w MNPP oraz GHI w MNPP ${ }^{16}$ ), w których jednak zaobserwowano zmianę o znacznie mniejszej wartości.

16 Spadek wartości współczynnika GHI dla gmin do 20 tys. mieszkańców w roku 2018 może zaskakiwać. Należy jednak pamiętać, że GHI jest (w porównaniu choćby do LHI) mniej czuły na wyniki najsłabszych ugrupowań. Stąd, obniżenie wartości współczynnika może świadczyć o postępującej konsolidacji lokalnych systemów partyjnych i powstrzymaniu się najsłabszych kandydatów oraz ugrupowań od kandydowania. Potwierdzają to dane obrazujące średnią liczbę komitetów zgłaszających kandydatów w gminach do 20 tys. (spadek z 6,93 do 5,30), jak również - zmniejszenie 
Co istotne, zaobserwowana wartość obu współczynników dla grupy badanej w roku 2018 jest znacznie niższa niż dla drugiej grupy kontrolnej (MNPP), stosującej taki sam system wyborczy. Wyjaśnienia można poszukiwać w liczbie komitetów oraz kandydatów aktywnych w wyborach w obu typach gmin. Średnia liczba komitetów wyborczych zgłaszających kandydatów w wyborach organu stanowiącego uległa zmniejszeniu we wszystkich trzech typach gmin, jednak to w gminach powyżej 20 tys. mieszkańców spadek ten był największy, zarówno w ujęciu względnym, jak i bezwzględnym (z 9,66 do 4,83 [o 50,05\%] w porównaniu ze spadkiem z 6,93 do 5,30 [o 23,61\%] w gminach do 20 tys. mieszkańców oraz z 7,95 do 6,59 [o 17,14\%] w MNPP. Łącznie, we wszystkich grupach, nastąpił spadek z 7,26 do 5,28 [o 27,21\%]). Stosunek średniej liczby komitetów w MNPP do gmin powyżej 20 tys. mieszkańców wzrósł z 0,82 do 1,37, co oznacza zmianę mocniejszą niż nawet odwrócenie proporcji.

Istotne zmiany między rokiem 2014 a 2018 nastąpiły również w odniesieniu do średniej liczby kandydatów na jeden mandat w poszczególnych grupach gmin. W roku 2014 była ona w grupie badanej znacznie wyższa niż w pierwszej grupie kontrolnej (do 20 tys. mieszkańców) - 4,97 względem 3,22 (o 54,25\% wyższa). Wyjaśnia to, przynajmniej częściowo, wyraźnie wyższe wartości współczynników LHI oraz GHI w grupie badanej w roku 2014. W tym samym roku jeszcze wyższa była średnia liczba kandydatów na jeden mandat w MNPP, jednak wartości tych nie można porównywać wprost $\mathrm{z}$ uwagi na inne konstrukcje list ${ }^{17}$. W roku 2018 średnia liczba kandydatów w przeliczeniu na 1 mandat w grupie badanej wzrosła z 4,97 do 6,18 [o 24,44\%], co należy wiązać z możliwością zgłoszenia większej liczby kandydatów niż liczba mandatów oraz wspomnianymi elementami systemu, zachęcającymi do zgłaszania jak największej liczby zarówno list, jak

średniej liczby kandydatów w tych samych gminach - zarówno w odniesieniu do całych rad, jak i pojedynczych mandatów (z 48,33 do 40,49 oraz z 3,22 do 2,70).

$17 \mathrm{~W}$ wyborach przeprowadzanych $\mathrm{z}$ wykorzystaniem formuły większości względnej w jednomandatowych okręgach wyborczych, każdy z komitetów może zgłosić wyłącznie jednego kandydata w każdym okręgu. W wyborach przeprowadzanych $\mathrm{z}$ wykorzystaniem formuły reprezentacji proporcjonalnej w wielomandatowych okręgach wyborczych jest to rozwiązywane na różne sposoby. W odniesieniu do wyborów do rad gmin w latach 2014 i 2018: w roku 2014 komitet mógł zgłosić w każdym okręgu minimum 5 kandydatów, maksymalnie zaś dwukrotną liczbę mandatów przeznaczonych do obsadzenia w okręgu. W roku 2018 - ponownie minimalnie 5 kandydatów, natomiast maksymalnie o dwóch więcej niż liczba mandatów przeznaczonych do rozdysponowania w okręgu. Zważywszy na sposób funkcjonowania poszczególnych systemów, w interesie komitetu wyborczego jest zgłaszanie maksymalnej możliwej liczby kandydatów w przypadku wyborów proporcjonalnych - obecność każdego z nich może przynieść zysk w postaci dodatkowych głosów. 
i kandydatów. Równocześnie nastąpił wyraźny spadek wysokości tego wskaźnika w MNPP (z 13,46 do 8,43 [o 37,35\%]). Należy wiązać to ze wspomnianym zmniejszeniem maksymalnej liczby kandydatów możliwych do zgłoszenia na listach wyborczych, zmniejszeniem się średniej liczby komitetów w MNPP, a pośrednio - z postępującą konsolidacją lokalnych systemów partyjnych.

Aby wykluczyć zafałszowanie wyników badania, które mogłoby zostać spowodowane przez wyraźny wzrost liczby mandatów przyznanych bez głosowania (mandaty niekonkurencyjne), badaniu poddano wysokość współczynników dysproporcjonalności w grupie badanej w wyborach w roku $2014^{18}$ oraz w pierwszej grupie kontrolnej w wyborach 2014 i 2018 roku z wyłączeniem gmin, w których przynajmniej jeden mandat został przyznany bez przeprowadzenia głosowania ${ }^{19}$.

Wyniki badania $\mathrm{z}$ wyłączeniem gmin, $\mathrm{w}$ których przynajmniej jeden mandat miał charakter niekonkurencyjny, wyklucza istotny wpływ zjawiska mandatów niekonkurencyjnych na całość badania. Mimo że wyniki dla obu wariantów są różne, nie są to różnice istotne. Po wykluczeniu gmin z mandatami niekonkurencyjnymi wartości współczynników LHI i GHI: dla gmin do 20 tys. mieszkańców w roku 2014 zmieniły się odpowiednio o $+0,0023$ oraz $-0,00316$ a w roku 2018: o -0,00551 i +0,01065; dla gmin powyżej 20 tys. mieszkańców w roku 2014: LHI $\mathrm{o}+0,00061$, zaś GHI pozostał praktycznie bez zmian (zmiana $\mathrm{o}-2,4^{\star} 10^{-6}$ ). Tak niewielkie różnice pozwalają wykluczyć wpływ zjawiska mandatów niekonkurencyjnych na wynik badania.

Aby wykluczyć kolejny czynnik, mogący zafałszować wyniki badania, średnie wartości współczynników dysproporcjonalności w grupie badanej przeanalizowano pod względem rodzaju gminy (wiejska, miejsko-wiejska, miejska) w latach 2014 i 2018. Wyniki zostały przedstawione na wykresie 2.

Wartości wszystkich współczynników uległy w roku 2018 wyraźnej redukcji, jednakże ich struktura uległa równocześnie zmianie. O ile w roku 2014, w odniesieniu do obu współczynników, najwyższe wartości zaobserwowano w przypadku gmin miejskich, zaś najniższe w gminach miejsko-wiejskich, to w roku 2018 najniższe (wyraźnie) wartości współczynników zaobserwowano w gminach wiejskich. Nie pozwala to na potwierdzenie bezpośredniego związku między typem gminy a poziomem proporcjonalności wyborów.

18 W gminach powyżej 20 tys. mieszkańców w wyborach w 2018 r. nie było przypadków mandatów niekonkurencyjnych, stąd nie istnieje potrzeba badania $\mathrm{z}$ ich wykluczeniem. To samo dotyczy wyborów w MNPP w obu elekcjach poddanych badaniu.

19 Stanowi to poszerzenie grupy gmin wykluczonych $\mathrm{z}$ badania, do której pierwotnie zaliczono wyłącznie gminy, w których wszystkie mandaty miały charakter niekonkurencyjny. 


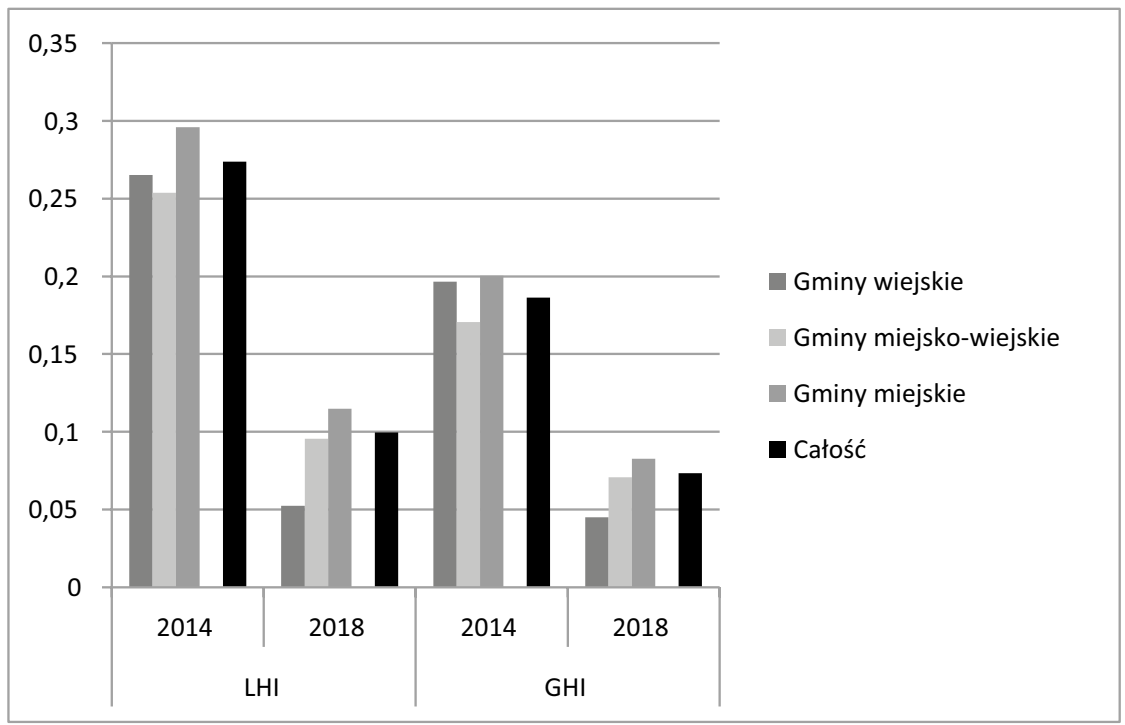

Wykres 2. Wartości współczynników dysproporcjonalności w podgrupach grupy badanej w latach 2014 i 2018

Źródło: Opracowanie własne na podstawie danych PKW.

Jako że badana grupa gmin jest wewnętrznie niejednorodna, szczególnie pod względem liczby mieszkańców danej jednostki (wedle stanu na 31 grudnia 2017, najmniejszą jednostką w grupie badanej była gmina Leżajsk - 20269 mieszkańców, największą natomiast gmina Piaseczno - 82526 mieszkańców), badaniu poddano zależność między liczbą mieszkańców a wysokością współczynników dysproporcjonalności w gminach w wyborach w latach 2014 i 2018. Badaniu poddano wszystkie gminy (niezależnie od przypisania do grupy badanej lub kontrolnej) z uwagi na fakt, że zastosowanie przedziałów wartości liczby mieszkańców w sposób automatyczny odseparowuje gminy poniżej 20 tys. mieszkańców, natomiast MNPP - z uwagi na ich liczbę (odpowiednio 65 i 66 w latach 2014 i 2018) oraz liczbę mieszkańców (w większości powyżej 100 tys. mieszkańców). Wyniki zostały przedstawione na wykresie 3.

Zaobserwowane nie potwierdzają liniowej zależności między liczbą mieszkańców a poziomem dysproporcjonalności (i zarazem proporcjonalności) wyborów. Potwierdza się natomiast wpływ zastosowanego systemu wyborczego na wysokość współczynników dysproporcjonalności. W każdym przypadku są one najwyższe w gminach do 20 tys. mieszkańców (system większościowy 


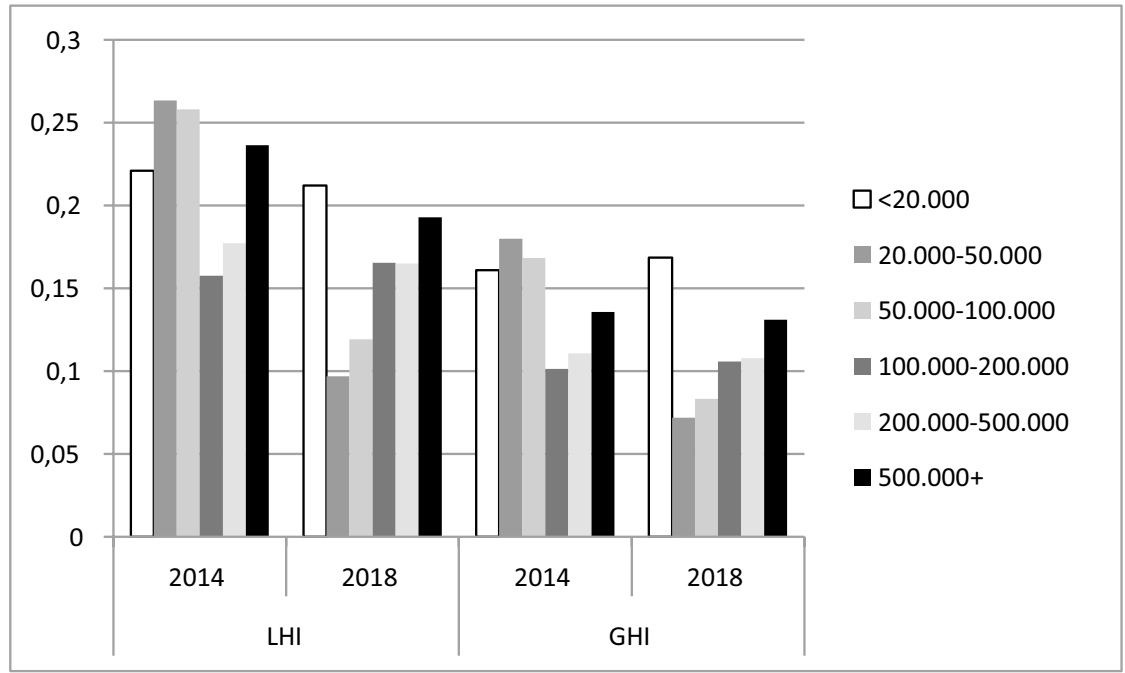

Wykres 3. Wartość współczynników dysproporcjonalności w wyborach do rad gmin w latach 2014 i 2018 względem liczby mieszkańców gminy

Źródło: Obliczenia własne na podstawie danych PKW.

w jednomandatowych okręgach wyborczych) oraz - w roku 2014 - w gminach do 100 tys. mieszkańców (wyraźna przewaga gmin z systemem większościowym w jednomandatowych okręgach wyborczych). Co może zastanawiać - w obrębie gmin stosujących dany system wyborczy (lub z wyraźną przewagą danego system), w większości przypadków dysproporcjonalność wzrasta wraz ze zwiększaniem się liczby mieszkańców (wyjątkiem są gminy 50- 100 tys. w roku 2014 oraz gminy 200-500 tys. tylko w zakresie LHI w roku 2018). Co istotne, w odniesieniu do największych gmin (powyżej 500 tys. mieszkańców) wartości współczynników dysproporcjonalności są bliskie zaobserwowanym dla gmin z wyborami większościowymi (a w roku 2014, w odniesieniu do LHI - wyższe niż w znacznej ich części). Można to tłumaczyć niewielką liczebnością grupy (zarówno w roku 2014 i 2018 n=5), jak również faktem względnie wysokiego rozwoju społeczeństwa obywatelskiego, w tym tzw. ruchów miejskich. Skutkuje to wyższym poziomem rozdrobnienia lokalnych systemów partyjnych, co wprost przekłada się na wartości współczynników. Takie wyjaśnienie potwierdza wartość współczynnika GHI względem LHI dla tych gmin w roku 2014 - znaczący wpływ na wysoką wartość LHI miały najmniejsze komitety wyborcze, prawdopodobnie 
komitety lokalnych aktywistów ${ }^{20}$. W tym kontekście zwraca uwagę znacznie mniejsza różnica wartości współczynników LHI i GHI w roku 2014, stanowiąca przesłankę potwierdzającą konsolidację lokalnych systemów partyjnych w tych gminach (będącą - przynajmniej w jakiejś mierze - efektem konsolidacji ugrupowań opozycji parlamentarnej przeciw lokalnej ofercie wyborczej rządzącego w kraju Prawa i Sprawiedliwości).

Czynnikiem wskazywanym (również przez twórców ustawy z 11 stycznia 2018) jako powodujący dysfunkcje na poziomie samorządu gmin jest długoletnie pełnienie funkcji przez WBP. Teoretycznie czynnik ten (czas urzędowania WBP) mógłby mieć wpływ na poziom proporcjonalności wyborów (choćby przez wpływ na konsolidację lokalnego systemu partyjnego lub podejmowanie przez WBP działań mających ograniczyć działalność środowisk opozycyjnych). Założenie to zostało zweryfikowane dzięki badaniu zależności między liczbą kolejnych zwycięskich wyborów przez WBP a wartością współczynników dysproporcjonalności w grupach gmin. Pod uwagę wzięto wyłącznie zwycięstwa w wyborach powszechnych (od 2002 roku), z wyłączeniem wyborów ponownych i przedterminowych. Nie uwzględniono również ewentualnej utraty przez WBP mandatu w trakcie kadencji, a jedynie sam fakt wyboru. Wyniki zostały przedstawione na wykresie 4.

Przedstawione dane nie potwierdzają hipotezy o wpływie czasu sprawowania władzy przez WBP na proporcjonalność wyborów. Wartości współczynników dysproporcjonalności pozostają na podobnym poziomie, niezależnie od liczby kadencji WBP. Również kierunek zmiany poziomu proporcjonalności wraz ze zwiększaniem się liczby kadencji WBP nie jest jednolity. Świadczy o tym w szczególności wzrost wartości współczynników LHI i GHI (w roku 2018) w tych gminach, w których WBP wygrywał we wszystkich wyborach powszechnych od 2002 roku, sprzeczny $\mathrm{z}$ tendencją zaobserwowaną dla wzrostu liczby kolejnych kadencji WBP w jednej do dwóch oraz z dwóch do trzech.

H2: Aby zbadać wpływ zmiany systemu wyborczego na możliwość uzyskania samodzielnej większości przez zwycięskie ugrupowanie, porównano częstość

20 Nie bez znaczenia pozostaje również fakt, że w największych miastach swoje listy wystawiają m.in. partie polityczne liczące się (lub aspirujące do takiego statusu) na płaszczyźnie ogólnokrajowej, niezależnie od faktycznej możliwości uzyskania wyniku dającego szansę na mandat. Ma to charakter prestiżowy i służy zarówno utrzymywaniu relacji z częścią elektoratu, jak i wykazaniu aktywności w trakcie procesu wyborczego (co ma szczególne znaczenie w obliczu koncentracji uwagi mediów na wyborach w wielkich miastach, kosztem np. sejmików województw). Przykładem może być np. wystawianie list w wyborach Rady Miasta Łodzi przez Polskie Stronnictwo ludowe do roku 2014, mimo braku realnej szansy uzyskania mandatu. Nawet mimo przekroczenia progu ustawowego (w roku 2014) uniemożliwiała to wysokość progów naturalnych. 


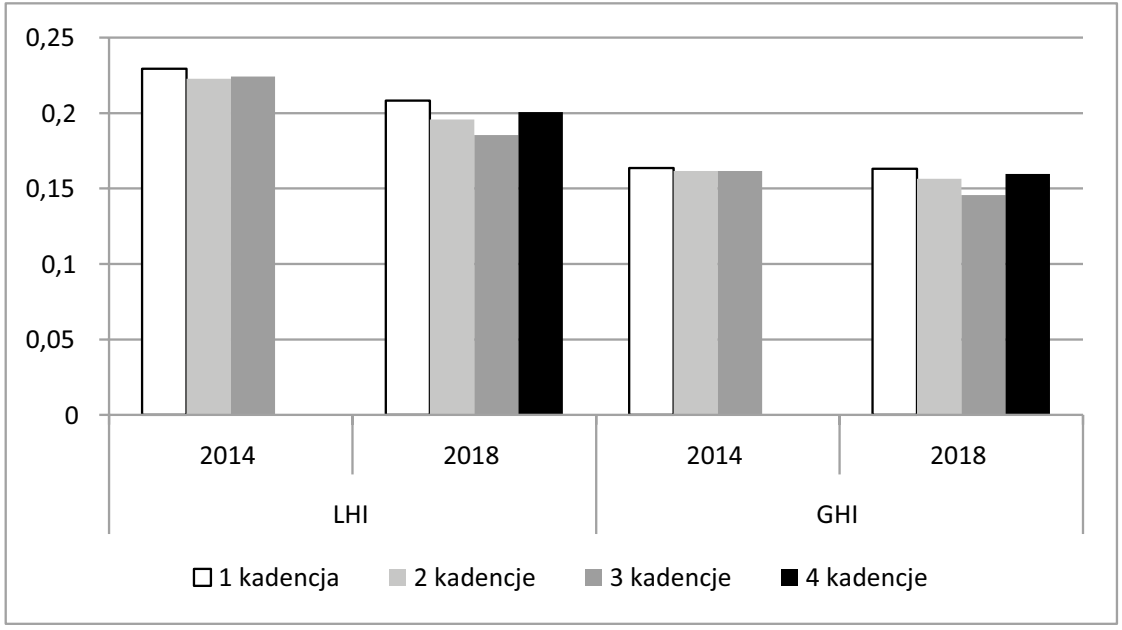

Wykres 4. Wartość współczynników dysproporcjonalności w wyborach rad gmin względem liczby kadencji urzędującego Wójta/Burmistrza/Prezydenta miasta Źródło: Opracowanie własne na podstawie danych PKW.

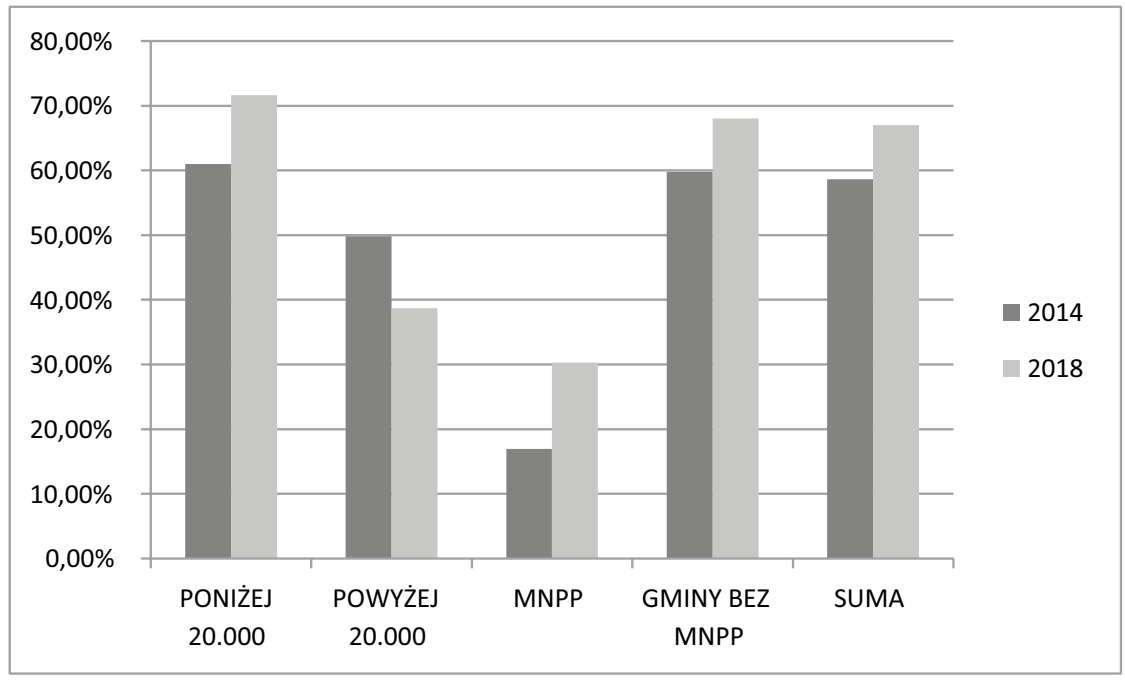

Wykres 5. Odsetek gmin, w których zwycięskie ugrupowanie uzyskało samodzielną większość w radzie gminy

Źródło: Opracowanie własne na podstawie danych PKW. 
uzyskiwania samodzielnej większości w grupach gmin w wyborach 2014 i 2018 roku. Wyniki zostały zaprezentowane na wykresie 5 .

Jedynie w przypadku grupy badanej odsetek gmin, w których zwycięskie ugrupowanie uzyskało samodzielną większość, obniżył się między rokiem 2014 a 2018 (z 49,81\% do 38,72\%). W pierwszej grupie kontrolnej (w której system wyborczy nie uległ zmianom) nastąpił wzrost o ponad 10 punktów procentowych (z 61,01\% do 71,65\%), podobnie jak w przypadku drugiej grupy kontrolnej. Różnice w wartościach między grupami kontrolnymi potwierdzają pozytywny wpływ formuły większościowej w jednomandatowych okręgach wyborczych na możliwość uzyskania samodzielnej większości przez jedno ugrupowanie oraz negatywny wpływ zastosowania formuły proporcjonalnej (nawet w małych i średnich okręgach) na prawdopodobieństwo uzyskania takiej większości. Wzrost wartości w obu grupach kontrolnych w roku 2018 może świadczyć o postępującej konsolidacji lokalnych systemów partyjnych.

Badaniu poddano możliwy związek między częstością uzyskania samodzielnej większości a liczbą kadencji WBP pełniącego funkcję w dniu głosowania. Wyniki przedstawiono w tabeli 1. Pod uwagę wzięto kadencje pełnione przez WBP w wyniku zwycięstwa w wyborach powszechnych (od 2002 roku).

Tabela 1. Odsetek gmin, w których zwycięskie ugrupowanie uzyskało samodzielną większość $\mathrm{w}$ radzie gminy w zależności od liczby kadencji WBP

\begin{tabular}{|l|c|c|c|c|c|c|c|c|c|}
\hline & & \multicolumn{7}{|c|}{ Rodzaj gminy } \\
\hline & & \multicolumn{2}{|c|}{ Poniżej 20 tys. } & \multicolumn{2}{|c|}{ Powyżej 20 tys. } & \multicolumn{2}{c|}{ MNPP } & \multicolumn{2}{c|}{ Całość } \\
\hline & & 2014 & 2018 & 2014 & 2018 & 2014 & 2018 & 2014 & 2018 \\
\hline \multirow{3}{*}{$\begin{array}{l}\text { Liczba } \\
\text { kadencji } \\
\text { WBP }\end{array}$} & 1 & $59,52 \%$ & $71,43 \%$ & $48,10 \%$ & $37,72 \%$ & $5,88 \%$ & $26,09 \%$ & $56,98 \%$ & $65,83 \%$ \\
\cline { 2 - 10 } & 2 & $63,07 \%$ & $73,44 \%$ & $48,51 \%$ & $43,48 \%$ & $23,81 \%$ & $50,00 \%$ & $60,57 \%$ & $70,08 \%$ \\
\cline { 2 - 10 } & 3 & $60,03 \%$ & $66,39 \%$ & $52,87 \%$ & $29,41 \%$ & $18,52 \%$ & $25,00 \%$ & $57,96 \%$ & $61,75 \%$ \\
\cline { 2 - 10 } & 4 & - & $78,86 \%$ & - & $52,63 \%$ & - & $23,08 \%$ & - & $74,56 \%$ \\
\hline
\end{tabular}

Źródło: Opracowanie własne na podstawie danych PKW.

Przedstawione wyniki nie potwierdzają liniowej zależności między liczbą kadencji WBP a możliwością uzyskania samodzielnej większości przez jedno ugrupowanie. Potwierdza się natomiast wpływ zmiany systemu wyborczego w grupie badanej - jedynie w gminach powyżej 20 tys. mieszkańców (bez MNPP) nastąpił spadek odsetka gmin, w których jedno ugrupowanie uzyskało samodzielną większość we wszystkich grupach określonych przez liczbę kadencji 
WBP urzędującego w dniu głosowania. We wszystkich pozostałych przypadkach odsetek ten zwiększył się.

H3: Dla weryfikacji hipotezy zbadano zmianę udziału procentowego najsilniejszego ugrupowania w zbiorze mandatów w latach 2014-2018 w badanych grupach. Wyniki zostały przedstawione w tabeli 2 .

Tabela 2. Udział najsilniejszego ugrupowania w zbiorze mandatów

\begin{tabular}{|c|c|c|c|c|c|c|c|c|c|c|}
\hline & & \multicolumn{9}{|c|}{ Gminy } \\
\hline & & \multicolumn{3}{|c|}{ Poniżej 20 tys. } & \multicolumn{3}{|c|}{ Powyżej 20 tys. } & \multicolumn{3}{|c|}{ MNPP } \\
\hline & & 2014 & 2018 & różnica & 2014 & 2018 & różnica & 2014 & 2018 & różnica \\
\hline \multirow{11}{*}{ 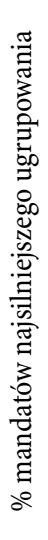 } & $0 \%-10 \%$ & $0,00 \%$ & $0,00 \%$ & $0,00 \%$ & $0,00 \%$ & $0,00 \%$ & $0,00 \%$ & $0,00 \%$ & $0,00 \%$ & $0,00 \%$ \\
\hline & $10 \%-20 \%$ & $0,37 \%$ & $0,05 \%$ & $-0,33 \%$ & $0,75 \%$ & $0,00 \%$ & $-0,75 \%$ & $1,54 \%$ & $0,00 \%$ & $-1,54 \%$ \\
\hline & $20 \%-30 \%$ & $3,08 \%$ & $1,12 \%$ & $-1,95 \%$ & $9,74 \%$ & $9,40 \%$ & $-0,34 \%$ & $4,62 \%$ & $3,03 \%$ & $-1,59 \%$ \\
\hline & $30 \%-40 \%$ & $20,62 \%$ & $13,36 \%$ & $-7,26 \%$ & $16,85 \%$ & $23,68 \%$ & $6,83 \%$ & $44,62 \%$ & $42,42 \%$ & $-2,19 \%$ \\
\hline & $40 \%-50 \%$ & $14,93 \%$ & $13,87 \%$ & $-1,05 \%$ & $22,85 \%$ & $28,95 \%$ & $6,10 \%$ & $32,31 \%$ & $25,76 \%$ & $-6,55 \%$ \\
\hline & $50 \%-60 \%$ & $29,15 \%$ & $28,21 \%$ & $-0,94 \%$ & $17,23 \%$ & $21,43 \%$ & $4,20 \%$ & $12,31 \%$ & $12,12 \%$ & $-0,19 \%$ \\
\hline & $60 \%-70 \%$ & $10,21 \%$ & $12,84 \%$ & $2,63 \%$ & $11,24 \%$ & $10,90 \%$ & $-0,33 \%$ & $4,62 \%$ & $10,61 \%$ & $5,99 \%$ \\
\hline & $70 \%-80 \%$ & $15,67 \%$ & $19,49 \%$ & $3,82 \%$ & $10,49 \%$ & $3,38 \%$ & $-7,10 \%$ & $0,00 \%$ & $6,06 \%$ & $6,06 \%$ \\
\hline & $80 \%-90 \%$ & $3,36 \%$ & $5,06 \%$ & $1,70 \%$ & $7,12 \%$ & $2,26 \%$ & $-4,86 \%$ & $0,00 \%$ & $0,00 \%$ & $0,00 \%$ \\
\hline & $90 \%-99 \%$ & $1,82 \%$ & $3,89 \%$ & $2,07 \%$ & $3,37 \%$ & $0,00 \%$ & $-3,37 \%$ & $0,00 \%$ & $0,00 \%$ & $0,00 \%$ \\
\hline & $100 \%$ & $0,79 \%$ & $2,11 \%$ & $1,32 \%$ & $0,37 \%$ & $0,00 \%$ & $-0,37 \%$ & $0,00 \%$ & $0,00 \%$ & $0,00 \%$ \\
\hline
\end{tabular}

Źródło: Opracowanie własne na podstawie danych PKW.

Otrzymane wyniki potwierdzają odmienną dynamikę udziału najsilniejszego ugrupowania w grupie badanej względem obu grup kontrolnych. Wyłącznie w grupie badanej zwiększeniu uległ udział gmin, w których najsilniejsze ugrupowanie uzyskało między $30 \%$ a $60 \%$ mandatów, w tym najwyższe wzrosty zaobserwowano w przedziale $30 \%-50 \%$. W obu grupach kontrolnych zaobserwowano wzrost odsetka gmin $\mathrm{z}$ wysokim udziałem najsilniejszego ugrupowania (powyżej $60 \%{ }^{21}$ ), przy czym najwyższe wartości, niezmiennie, dotyczą najmniejszych gmin. W jeszcze większym stopniu, różnica jest zauważalna dla sytuacji zdobycia

21 Może być to traktowane jako kolejna przesłanka świadcząca o konsolidacji lokalnych systemów partyjnych. 
wszystkich mandatów przez jedno ugrupowanie ${ }^{22}$ : w grupie badanej wystąpiło to jednokrotnie w roku 2014 (Kutno w województwie łódzkim), natomiast w roku 2018 nie tylko nie powtórzyło się, ale też żadne z ugrupowań nie przekroczyło granicy $90 \%$ mandatów. Potwierdza to pozytywny wpływ zastosowania formuły większości względnej w jednomandatowych okręgach wyborczych a prawdopodobieństwem uzyskania samodzielnej większości.

Zastosowanie metod obliczania wartości progów naturalnych pozwala na pogłębienie analizy. Możliwość uzyskania wszystkich mandatów jest uzależniona zarówno od stosowanej formuły wyborczej, od liczby mandatów w okręgu oraz od liczby zgłoszonych list. Przykładowo: w gminie do 20 tys. mieszkańców (15 mandatów w 15 okręgach), przy 4 listach (kandydatach) do każdego mandatu, (teoretycznie) możliwe jest uzyskanie wszystkich mandatów już przy poparciu przekraczającym $25 \%$. Jeżeli w tych samych warunkach zastosowano by okręgi 5-mandatowe oraz metodę D’Hondta, a w każdym okręgu zgłoszono by 4 listy, minimalne poparcie (teoretycznie) umożliwiające uzyskanie wszystkich mandatów wyniosłoby $62,5 \%$. Liczba mandatów w gminie powyżej 20 tys. mieszkańców nie może być mniejsza niż 21. Dla takiej liczby najkorzystniejsza (z punktu widzenia możliwości uzyskania wszystkich mandatów przez jedno ugrupowanie) struktura okręgów możliwa do zastosowania w ramach istniejącego systemu wyborczego to trzy okręgi 5-mandatowe i jeden 6-mandatowy. Podtrzymując założenie o 4 listach w każdym okręgu, minimalne poparcie umożliwiające uzyskanie wszystkich mandatów wynosi nieznacznie powyżej 63,69\%. Uzyskanie takiego poparcia oznacza jednak wyłącznie, że uzyskanie wszystkich mandatów jest teoretycznie możliwe, nadal jednak nieprawdopodobne (wymagałoby to, dodatkowo, idealnego rozkładu pozostałych głosów). Pewność uzyskania wszystkich mandatów wymagałaby uzyskania poparcia 83,34\% w każdym okręgu 5-mandatowym oraz $85,72 \%$ w okręgu 6-mandatowym, co oznacza nie mniej niż $84,02 \%$ w skali całej rady (przy idealnym rozłożeniu pozostałych głosów).

22 W badaniu pominięto gminy, w których nie odbyło się głosowanie, a wszystkie mandaty przydzielono kandydatom jednego ugrupowania: w roku 2014: Rutka-Tartak (gmina poniżej 20 tys. mieszkańców, powiat suwalski, województwo podlaskie; w roku 2018 (wyłącznie gminy do 20 tys.: Pęcław powiat głogowski, województwo dolnośląskie; Dragacz powiat świecki, województwo kujawsko-pomorskie; Tarnawatka powiat tomaszowski, województwo lubelskie; Korczew powiat siedlecki, województwo mazowieckie; Czarna powiat bieszczadzki, województwo podkarpackie; Jasienica Rosielna powiat brzozowski, województwo podkarpackie; Bakałarzewo powiat suwalski, województwo podlaskie; Wisła powiat cieszyński, województwo śląskie; Suszec powiat pszczyński, województwo śląskie; Krzanowice powiat raciborski, województwo śląskie; Kowale Oleckie powiat olecki, województwo warmińsko-mazurskie. 
100\% pewność uzyskania wszystkich mandatów, niezależnie od rozłożenia poparcia między okręgami, wymagałoby uzyskania nie mniej niż 95,87\%. Wskazane wartości progów naturalnych dla opisanej sytuacji wskazują, jak wysokie musiałoby być poparcie dla zwycięskiego ugrupowania, aby zmonopolizować radę. Zważywszy na fakt, że w grupie badanej w roku 2018 uzyskanie poparcia powyżej 63,69\% miało miejsce bardzo rzadko (w 11 przypadkach, co oznacza $4,14 \%$ gmin w grupie badanej), powyżej $70 \%$ jedynie w 5 przypadkach $(1,88 \%)$, nie zaobserwowano natomiast ani jednego przypadku uzyskania poparcia powyżej 90\% (najwyższe poparcie dla zwycięskiego ugrupowania zaobserwowano w gminie Jasienica, powiat bielski, woj. śląskie - wyniosło ono 86,95\% i był to jedyny przypadek poparcia powyżej $80 \%$ ), scenariusz uzyskania wszystkich mandatów przez jedno ugrupowanie można uznać za praktycznie wykluczony.

H4: W celu weryfikacji hipotezy zbadano liczbę oraz częstość występowania zwycięskich kandydatów na WBP kandydujących również do rad w wyborach 2014 i 2018 (w całym zbiorze oraz w grupach gmin). Ponadto wyszczególniono grupę kandydatów na WBP w gminach do 20 tys. Mieszkańców, kandydujących równocześnie do rady gminy do 20 tys. mieszkańców. Wyniki zostały przedstawione na wykresie 6.

Gminy poniżej 20 tys. mieszkańców stanowią jedyną grupę, w której zaobserwowano spadek zarówno liczby (z 688 do 155), jak i odsetka (z 32,21\% do 7,23\%) zwycięskich kandydatów na WBP, którzy kandydowali równocześnie do organów stanowiących JST. Jednak gdy wykluczono kandydatów na WBP kandydujących do organów stanowiących innych JST, zaobserwowano wyraźny wzrost zarówno liczbowy (ze 112 do 155), jak i procentowy (z 5,28\% do 7,23\%). Potwierdza to hipotezę o zwiększeniu częstości kandydowania zarówno do organu wykonawczego, jak i stanowiącego gminy do 20 tys. mieszkańców wśród zwycięzców wyborów, a przez to - zwiększenia kosztów związanych z potrzebą organizacji wyborów uzupełniających ${ }^{23}$.

23 Podobną zmianę zaobserwowano również wśród wszystkich kandydatów na WBP w gminach do 20 tys. mieszkańców (niezależnie od uzyskania mandatu WBP) - liczba kandydujących równocześnie do organów stanowiących JST spadła z 3214 do 1393 (w ujęciu procentowym: z 50,16\% do 24,81\%). Gdy jednak wykluczyć kandydujących w różnych JST, wartości te wzrosły z 994 do 1393 (i z 15,46\% do 24,81\%). W roku 2014 oprócz kandydujących w tej samej gminie, 7 kandydowało do rady innej gminy do 20.000 mieszkańców, 11 do rady innej gminy powyżej 20 tys. mieszkańców, 7 do rady MNPP, 1965 do rady powiatu, w skład którego wchodziła dana gmina, 8 do rady innego powiatu oraz 222 do sejmików województw. 


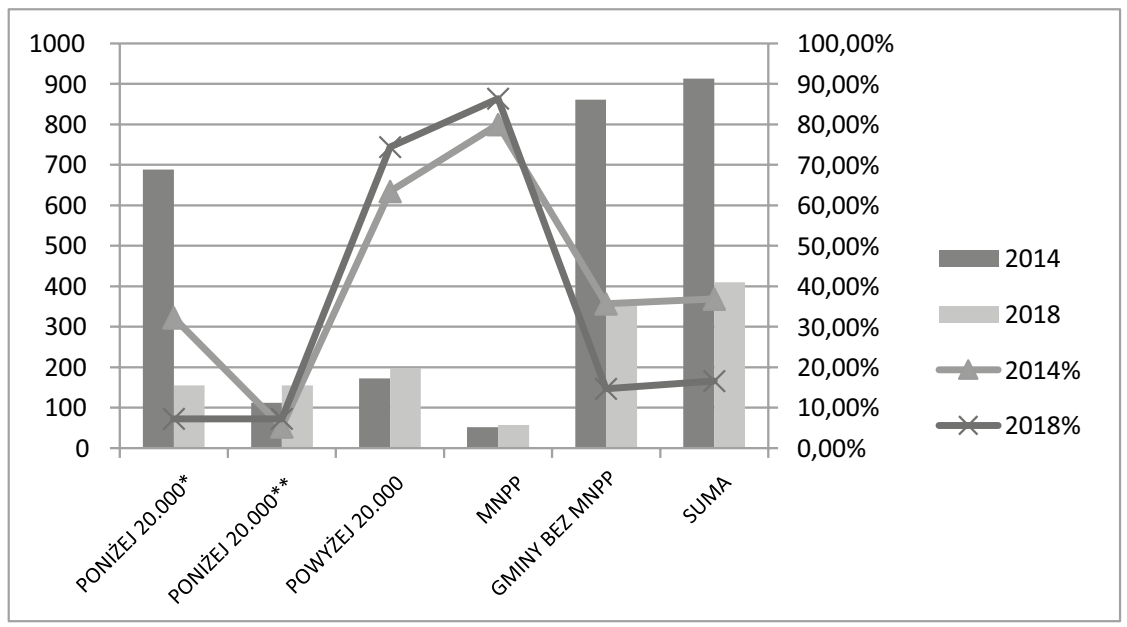

Wykres 6. Liczba oraz częstość występowania zwycięskich kandydatów na WBP kandydujących również do rad w wyborach 2014 i 2018

*Kandydaci na WBP w gminach do 20 tys. mieszkańców kandydujący równocześnie do rad niezależnie od poziomu JST ( $w$ roku 2014: 112 do rad gmin do 20 tys., 497 kandydujących do rady powiatu, w skład którego wchodzi ta gmina, 2 do rady innego powiatu, 77 do sejmiku województwa w skład którego wchodzi dana gmina).

**Kandydaci na WBP w gminach do 20 tys. mieszkańców kandydujący równocześnie do rady gminy do 20 tys. mieszkańców (w roku 2014: we wszystkich przypadkach była to ta sama gmina).

Źródło: Opracowanie własne na podstawie danych PKW.

\section{WNIOSKI}

Analizując zebrany materiał badawczy, Autorom udało się w przeważającej mierze udowodnić postawione we wstępie hipotezy. Przyjrzyjmy się im jednak bardziej szczegółowo.

H1: Porównując wybory samorządowe z lat 2014 i 2018, na podstawie wartości współczynników LHI i GHI, potwierdzono, iż wyniki elekcji z 2018 roku były bardziej proporcjonalne w odniesieniu do wyników głosowania. Nastąpiło to we wszystkich grupach, jednak w grupie badanej, czyli w gminach powyżej 20 tys. mieszkańców niebędących MNPP, wzrost proporcjonalności jest zdecydowanie najwyższy. Częściowo zmiany te można wytłumaczyć postępującą konsolidacją lokalnych scen politycznych, to jednak w przypadku grupy badanej, za tak dużą 
zmianę musi odpowiadać reforma systemowa. Z punktu widzenia wyborców istotny jest także fakt, że zjawisku temu nie towarzyszył spadek liczby kandydatów w przeliczeniu na mandat. Zmiana systemowa spowodowała co prawda spadek średniej liczby komitetów w gminie (formuła proporcjonalna eliminuje praktycznie komitety jednoosobowe), jednak wzrost liczby kandydatów spowodował de facto poszerzenie oferty wyborczej.

Przy okazji tego badania nie udało się potwierdzić istotnego wpływu na proporcjonalność wyborów takich czynników jak typ gminy, jej wielkość wyrażona liczbą mieszkańców, a także liczba kadencji pozostawania przy władzy lokalnego WBP.Zwłaszcza typ gminy okazuje się mieć znaczenie głównie administracyjne, toteż Autorzy nie zachęcają do wykorzystania tego aspektu w badaniach wyborów i systemów wyborczych. Do zaskakujących wniosków doprowadziła analiza wpływu zjawiska mandatów niekonkurencyjnych na poziom proporcjonalności (w gminach wykorzystujących formułę większościową). Wyniki badania wskazują, że nie wpływa ono w sposób istotny na proporcjonalność wyborów ${ }^{24}$.

H2: Zmiana systemu wyborczego w grupie badanej doprowadziła do zdecydowanego spadku liczby ugrupowań dysponujących samodzielną większością. Ponadto w grupach kontrolnych zaobserwowano dokładnie odwrotną tendencję. Wychodząc z założenia, że rządy jednego ugrupowania są z zasady bardziej stabilne niż rządy koalicyjne, można zaryzykować stwierdzenie, iż w grupie badanej udało się osiągnąć wyższy poziom odwzorowania decyzji wyborów, jednak za cenę pewnego obniżenia poziomu stabilności rządów.

H3: Wybory z 2018 roku w grupie badanej potwierdziły wyraźnie, iż uzyskanie $100 \%$ mandatów przez jedno ugrupowania jest praktycznie niemożliwe. $\mathrm{W}$ analizowanej elekcji w żadnej gminie w grupie badanej żadnemu ugrupowaniu nie udało się uzyskać nawet $90 \%$ mandatów.

H4: Mimo że zarówno ogólna liczba, jak i odsetek kandydatów na WBP, startujących równocześnie do rad, w najmniejszych gminach uległy ograniczeniu wskutek braku możliwości równoczesnego kandydowania do innych rad niż rada tej samej gminy, w odniesieniu do kandydatów startujących do rady tej samej gminy uległy wyraźnemu wzrostowi. Podobne obserwacje dotyczą kandydatów zwycięskich w tych gminach. Potwierdzono zatem zwiększenie liczby przypadków oraz częstości takiej sytuacji. Z uwagi na fakt, że w gminach do 20 tys. mieszkańców równoczesny wybór na WBP oraz do rady skutkuje

24 Poza sytuacjami, w których wszystkie mandaty zostają przyznane bez przeprowadzenia głosowania. Te przypadki zostały wyłączone $\mathrm{z}$ badania. 
koniecznością przeprowadzenia wyborów uzupełniających (w przeciwieństwie do większych gmin, gdzie ma zastosowanie formuła reprezentacji proporcjonalnej, a zwolniony mandat zostaje przyznany bez konieczności przeprowadzenia kolejnego głosowania), potwierdza się wzrost związanych z tym kosztów. Z uwagi fakt, że dotyczyło to przeszło 155 gmin, należy rozważyć postulat ponownego umożliwienia kandydowania do innych rad, w szczególności do rady powiatu oraz sejmiku województwa, na obszarze których znajduje się dana gmina.

\section{BiBLIOGRAFIA:}

Balicki, R. (2018). Zmiana zasad tworzenia okręgów wyborczych w wyborach samorządowych w nowelizacji Kodeksu wyborczego z 2018 r. Przegląd Prawa Konstytucyjnego, 4 (44), 57-69. DOI:10.15804/ppk.2018.04.04.

Benoit, K. (2000). Which Electoral Formula Is the Most Proportional? A New Look with New Evidence. Political Analysis, 8(4), 381-388. DOI:10.1093/oxfordjournals. pan.a029822.

Czapiewski, T., Miszczuk, R. (2019). Wpływ zmian polskiego prawa wyborczego w 2018 roku na proces przygotowania i przeprowadzenia wyborów. Acta Iuris Stetinensis, 3(27), 53-80. DOI:10.18276/ais.2019.27-04.

Flis, J., Stolicki, D. (2017). JOW-y w gminach: lokalne partie władzy a nowe reguły rywalizacji. Ruch Prawniczy, Ekonomiczny i Socjologiczny, 3(79), 253-266. DOI:10.14746/ rpeis.2017.79.3.20.

Frydrych-Depka, A. (2018). Instytucja komisarza wyborczego i urzędników wyborczych po nowelizacji kodeksu wyborczego. Studia Iuridica Toruniensia, XXIII, 55-72. DOI:10.12775/SIT.2018.028.

Gallagher, M. (1991). Proportionality, Disproportionality and Electoral Systems. Electoral Studies, 10, 33-51.

Gallagher, M. (1992). Comparing Proportional Representation Electoral Systems: Quotas, Thresholds, Paradoxes and Majorities. British Journal of Political Science, vol. 22(4), 469-496. DOI:10.1017/S0007123400006499.

Gendźwiłł, A., Żółtak, T. (2016). Skutki wprowadzenia okręgów jednomandatowych w wyborach lokalnych. Studia Regionalne i Lokalne, 3(65), 94-116. DOI:10.7366/1509499536505.

Gendźwiłł, A., Żółtak, T. (2020). Ile partii w samorządzie? Partie sejmowe i listy lokalne $\mathrm{w}$ wyborach władz gmin w latach 2002-2018. Studia Regionalne i Lokalne, 2(80), 40-66. DOI:10.7366/1509499528003.

Glinka, K. (2020). Polityczne konsekwencje zmiany formuły wyborczej i wprowadzenia ograniczeń w kandydowaniu - przypadek wyborów do rad dużych i średnich miast województwa dolnośląskiego z lat 2014 i 2018. Przegląd Prawa Konstytucyjnego, 2(60), 155-172. DOI:10.15804/ppk.2021.02.10. 
Groffman, B., Taagepera, R. (2003). Mapping the Indices of Seats-Votes Disproportionality and Inter-Election Volatility. Party Politics, 9(6), 659-677. DOI:10.1177/13540688030096001.

Haman, J. (2018). Wybory samorządowe 2018. Raport z obserwacji. Pobrane z: http:// obserwatoriumdemokracji.pl/wp-content/uploads/2019/01/Wybory-samorzadowe-2018-Raport-z-badania.pdf.

Hermeliński, W. (2018). Aktualne problemy prawa wyborczego przed wyborami do jednostek samorządu terytorialnego. Przegląd Prawa Konstytucyjnego, 4(44), 11-18. DOI:10.15804/ppk.2018.04.01.

Loosemore, J., Hanby, V. J. (1971). The Theoretical Limits of Maximum Distortion: Some Analytical Expressions for Electoral Systems. British Journal of Political Science, 1, 467-77. DOI:10.1017/S000712340000925X.

Masternak-Kubiak, M. (2018). Rola sądu administracyjnego w procesie podziału gminy na okręgi wyborcze. Przeglad Prawa Konstytucyjnego, 4(44), 71-86. DOI:10.15804/ ppk.2018.04.05.

Michalak, B. (2018). Zmiana przepisów Kodeksu wyborczego przed wyborami samorządowymi 2018. Athenaeum. Polskie Studia Politologiczne, 58, 75-99. DOI: 10.15804/ athena.2018.58.05.

Michalak, B. (2019). Ocena funkcjonalności zmian wprowadzonych do Kodeksu wyborczego w 2018 roku w świetle doświadczeń wyborów samorządowych. Studia Wyborcze, 28, 55-73. DOI: 10.26485/SW/2019/28/4.

Neumann, J. (2020). Zmiana systemu $\mathrm{z}$ większościowego na proporcjonalny w gminach powyżej 20 tysięcy mieszkańców w województwie łódzkim jako czynnik oddziałujący na liczbę i charakter komitetów wyborczych. Studia Wyborcze, 29, 99-122. DOI: $10.26485 / \mathrm{SW} / 2020 / 29 / 5$.

Niżnik-Mucha, A. (2018). Wybrane zmiany kodeksu wyborczego w świetle konstytucyjnych zasad prawa wyborczego. Casus, 91, 11-15.

Onasz, M., Klonowski, M. (2018). Wybrane zmiany w systemie wyborczym organów jednostek samorządu terytorialnego wynikające z ustawy o zmianie niektórych ustaw w celu zwiększenia udziału obywateli w procesie wybierania, funkcjonowania i kontrolowania niektórych organów publicznych - wstępna ocena. Studia regionalne i lokalne, 2(72), 99-117. DOI: 10.7366/1509499527206.

Pyrzyńska, A. (2020). Obwodowe komisje wyborcze w wyborach samorządowych. Wybrane zagadnienia na tle praktyki wyborów z 2018 r. Przegląd Prawa Konstytucyjnego, 1(53), 193-213. DOI:10.15804/ppk.2020.01.12.

Rae, D., Hanby, V. J., Loosemore, J. (1971). Thresholds of representation and thresholds of exclusion: An analytic note on electoral systems. Comparative Political Studies, 3(4), 479-488. DOI:10.1177/001041407100300406.

Rakowska-Trela, A. (2018a). Nowelizacja samorządowego prawa wyborczego z 2018 r. Przeglad Prawa Konstytucyjnego, 4(44), 19-35. DOI:10.15804/ppk.2018.04.02.

Rakowska-Trela, A. (2018b). Zasada demokratycznego państwa prawnego a zmiany w prawie wyborczym. Studia Wyborcze, 25, 17-30. DOI:10.26485/SW/2018/25/2. 
Rulka, M. (2018). Na temat zgodności projektu ustawy o zmianie niektórych ustaw w celu zwiększenia udziału obywateli w procesie wybierania, funkcjonowania i kontrolowania niektórych organów publicznych (druk nr 2001) - w części zmieniającej przepisy kodeksu wyborczego - z europejskimi standardami wyborczymi. Przegląd Sejmowy, 1(144), 165-179.

Stępień, P. (2018). Wybory niekonkurencyjne do organów stanowiących jednostek samorządu terytorialnego w Polsce. Łódź: Repozytorium Uniwersytetu Łódzkiego.

Sokala, A. (2018). Zmiany w systemie polskiej administracji wyborczej. Studia Wyborcze, 25, 45-56. DOI:10.26485/SW/2018/25/4.

Taagepera, R., Shugart, M. S. (1989). Seats and Votes: the Effects and Determinants of Electoral Systems. New Haven: Yale University Press.

Urbaniak, K. (2020). Zasada proporcjonalności w samorządowym prawie wyborczym. Przegląd Prawa Konstytucyjnego, 4(44), 37-56. DOI: 10.15804/ppk.2018.04.03.

Ustawa z dnia 5 stycznia 2011 r. - Kodeks wyborczy, Dz.U. 2011 nr 21 poz. 112 z późn. $\mathrm{zm}$.

Ustawa z dnia 11 stycznia 2018 r. o zmianie niektórych ustaw w celu zwiększenia udziału obywateli w procesie wybierania, funkcjonowania i kontrolowania niektórych organów publicznych, Dz.U. 2018 poz. 130.

Woźnicki, M. (2018). Rola komisarza wyborczego w procedurze podziału gmin na okręgi wyborcze w wyborach do rad gmin w świetle Kodeksu wyborczego. Przeglad Prawa Konstytucyjnego, 4(44), 121-143. DOI:10.15804/ppk.2018.04.08.

Woźnicki, M. (2020). Ewolucja podstawowych zasad polskiego prawa wyborczego w wyborach do organów stanowiących jednostek samorządu terytorialnego i w wyborach parlamentarnych w Polsce po 1989 r. Przeglad Prawa Konstytucyjnego, 1(53), 75-89. DOI:10.15804/ppk.2020.01.04.

\section{Bazy danych:}

Dane Państwowej Komisji Wyborczej dot. Wyborów samorządowych 2002-2018. www. pkw.gov.pl.

Główny urząd statystyczny. www.stat.gov.pl. 